Teknik, 37(2), 2016, 59-63

\title{
Analisis Desain Sistem Pembangkit Listrik Tenaga Surya Kapasitas 50 WP
}

\author{
Anwar Ilmar Ramadhan*, Ery Diniardi, Sony Hari Mukti \\ Jurusan Teknik Mesin, Fakultas Teknik, Universitas Muhammadiyah Jakarta \\ Jl. Cempaka Putih Tengah No 27 Jakarta 10510 Indonesia
}

\begin{abstract}
Abstrak
Kebutuhan akan listrik baik untuk kalangan industri, perkantoran, maupun masyarakat umum dan perorangan sangat meningkat. Tetapi, peningkatan kebutuhan listrik ini tidak diiringi oleh penambahan pasokan listrik. Berdasarkan permasalahan tersebut, energi surya dipilih sebagai energi alternatif untuk menghasilkan energi listrik. Alat yang digunakan disini adalah sel surya, karena dapat mengkonversikan langsung radiasi sinar matahari menjadi energi listrik (proses photovoltaic). Agar energi surya dapat digunakan pada malam hari, maka pada siang hari energi listrik yang dihasilkan disimpan terlebih dahulu ke baterai yang dikontrol oleh regulator. Keluaran regulator langsung dihubungkan dengan inverter dari arus DC ke AC. Hasil pengujian modul surya (photovoltaic) terlihat bahwa hasil daya keluaran rata-rata mencapai 38,24 Watt,dan arus yang didapatkan sebesar 2,49 A (Ampere). Hal ini dikarenakan photovoltaic saat mengikuti arah pergerakan matahari akan selalu memposisikan photovoltaic untuk tetap menghadap matahari sehingga tetap akan dapat menangkap pancaran matahari secara maksimal.
\end{abstract}

Kata kunci: Sel Surya; Analisis Desain; Sistem Photovoltaic; energi listrik

\begin{abstract}
[Title: Design Analysis of System Power Solar Cells Capacity of $50 \mathrm{Wp}$ ] The need for electricity is good for the industry, offices, and public and individuals are greatly increased. However, the increase in demand for electricity is not accompanied by the additional power supply. Based on these problems, chosen solar energy as an alternative energy to generate electric power. A tool that is used here is the solar cell because it can directly convert solar radiation into electrical energy (photovoltaic process). So that solar energy can be used at night, then during the day, the electrical energy generated is stored before a battery which is controlled by the regulator. Regulator output is directly connected to the inverter from the DC to AC. The test results of solar modules (photovoltaic) indicated that the results of the average power output reached 38.24 Watt, and the currents were 2.49 A. This is because the photovoltaic follows the direction of movement of the sun and always located at the photovoltaic to remain facing the sun. Therefore, it will still be able to capture the radiant sun to the fullest.
\end{abstract}

Keywords: Solar Cell; Design Analysis; Photovoltaic System; Electric Power

\section{Pendahuluan}

Energi adalah kemampuan untuk melakukan pekerjaan. Energi adalah daya yang dapat digunakan untuk melakukan berbagai proses kegiatan meliputi energi mekanik, panas, dan lain - lain. Oleh karena itu, hampir semua perselisihan di dunia ini, berpangkal pada perebutan sumber energi. Ada beberapa energi alam sebagai energi alternatif yang bersih, tidak berpolusi, aman dan persediaannya tidak terbatas yang dikenal dengan energi terbarukan (Akhmad, 2011).

Sumber energi baru dan yang terbarukan di masa mendatang akan semakin mempunyai peran yang sangat

\footnotetext{
${ }^{*}$ Penulis Korespondensi.

E-mail: anwar.ilmar@ftumj.ac.id
}

penting dalam memenuhi kebutuhan energi. Hal ini disebabkan oleh penggunaan bahan bakar fosil untuk pembangkit - pembangkit listrik konvesional dalam jangka waktu yang panjang akan menguras sumber minyak bumi, gas dan batu bara yang cadangannya semakin lama semakin menipis (Anggara dkk., 2014).

Di Indonesia yang terletak di daerah tropis ini sebenarnya memiliki suatu keuntungan cukup besar yaitu menerima sinar matahari yang berkesinambungan sepanjang tahun. Sayangnya energi tersebut kelihatannya dibiarkan terbuang percuma untuk keperluan alamiah saja (Hasan, 2012). Selain itu energi matahari dapat dimanfaatkan dengan bantuan peralatan lain, yaitu dengan merubah radiasi matahari kebentuk lain. Ada dua macam cara merubah radiasi matahari ke dalam energi lain, yaitu melalui solar cell dan collector 
Teknik, 37 (2), 2016, 60

(Karmiathi, 2012). Tidak diragukan lagi bahwa energi surya adalah salah satu sumber energi yang ramah lingkungan dan sangat menjanjikan pada masa yang akan datang, karena tidak ada polusi yang dihasilkan selama proses konversi energi, dan juga sumber energinya banyak tersedia di alam (Rahayuningtyas, dkk, 2014).

Oleh karena itu penerapan teknologi Pembangkit Listrik Tenaga Surya (PLTS) untuk memanfaatkan potensi energi surya yang tersedia dilokasi-lokasi tersebut merupakan solusi yang tepat (Subandi dkk., 2015). PLTS atau lebih dikenal dengan sel surya (sel Photovoltaic) akan lebih diminati karena dapat digunakan untuk berbagai keperluan yang relevan dan di berbagai tempat seperti perkantoran, pabrik, perumahan, dan lainnya. Sehingga hal ini dipandang perlu untuk dikaji lebih lanju, agar diperoleh kajian yang komprehensif secara teknik (Ubaidillah dkk., 2012).

Dalam penelitian ini akan menganalisis desain hasil rancangan sistem pembangkit listrik tenaga surya kapasitas 50 WP pada skala laboratorium. Dengan tujuan penelitian untuk menghitung karakteristik pembangkit listrik tenaga surya dengan menggunakan Solar Cell 50 WP dan menghitung daya maksimal yang dihasilkan oleh pembangkit listrik tenaga surya yang dihasilkan. Sehingga dapat dianalisis unjuk kerja dari desain sistem pembangkit listrik tenaga surya untuk kapasitas $50 \mathrm{WP}$.

\section{Metode Penelitian}

Metode yang digunakan dalam desain analisis rangkaian dilakukan beberapa tahapan, diantaranya: (a). Penentuan panel surya yang digunakan, sehingga dalam penggunaannya tidak terjadi kerusakan pada panel surya itu sendiri; (b). Penentuan komponen regulator yang akan digunakan, sehingga dalam aplikasinya tidak terjadi kesalahan penggunaan yang berakibat kurang baik atau dapat merusak panel surya maupun peralatan listrik yang dipasang nantinya; (c). Dari segi penggunaan komponen, juga dipertimbangkan segi ekonomis dan kondisi yang ada dipasaran, sehingga dalam pencarian komponen tidak mengalami kesulitan.; (d). Dari segi estetika, desain alat agar dapat dibuat sedemikian rupa sehingga rapi, menarik dan aman dalam penggunaannya; (f). Memilih komponen yang lulus kualifikasi dan sesuai dengan kebutuhan sistem, seperti $\mathrm{BCR}$ dan inverter (jika terdapat beban AC). Metodologi yang digunakan dalam desain analisis pembangkit listrik tenaga matahari 50 WP dapat digambarkan dalam bentuk diagram alir (flowchart) yang sistematis seperti Gambar 1.

\section{Hasil dan Pembahasan}

Langkah awal dalam penelitian ini adalah melakukan kajian literatur dan perancangan sistem yang berkaitan mengenai sistem pembangkit listrik tenaga sel surya seperti disajikan pada Gambar 2.

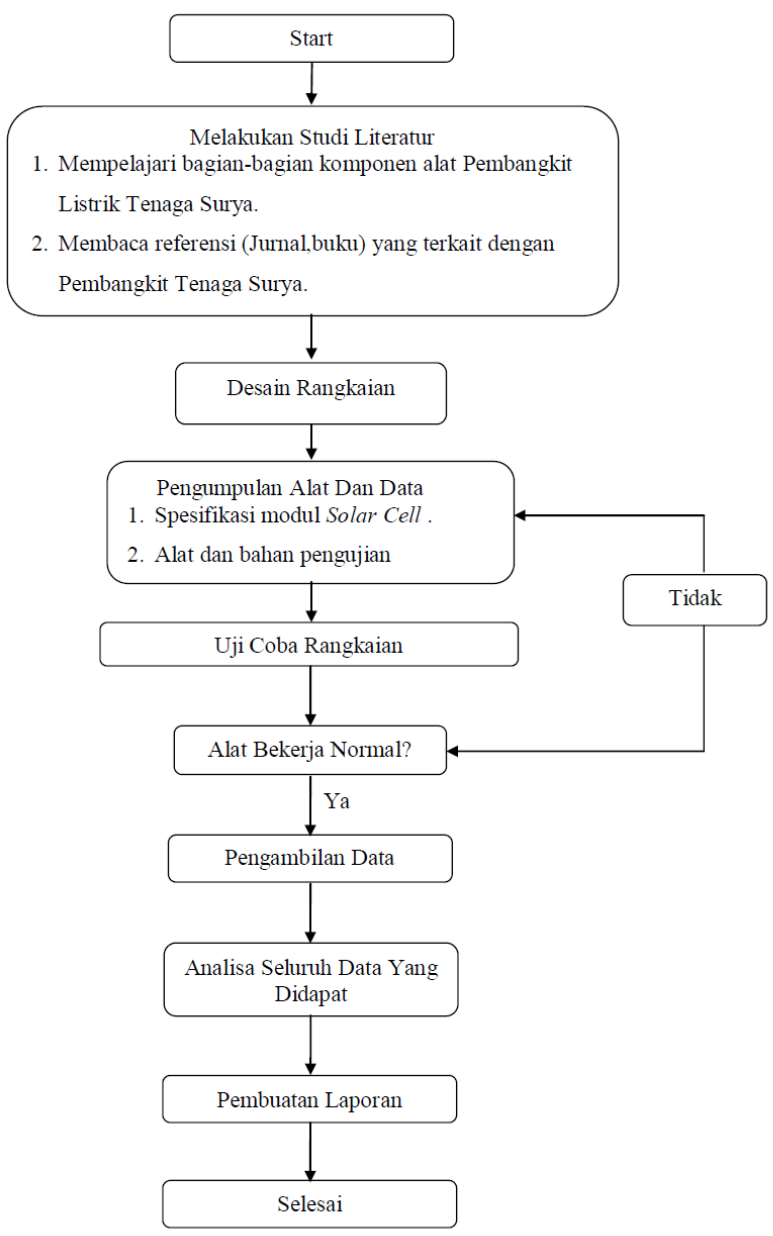

Gambar 1. Diagram alur penelitian

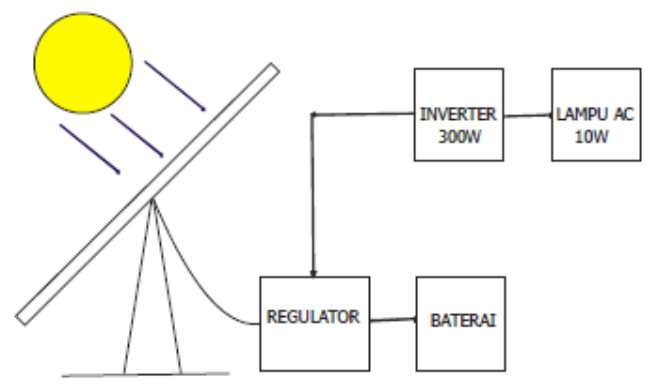

Gambar 2. Rangkaian Pemasangan Sel surya 50 WP

Berdasarkan Gambar 2, diagram blok PLTS yang dirancang, maka prinsip kerja dari Simulasi Pembangkit Listrik Tenaga Surya (PLTS) yang dibuat adalah sebagai berikut: matahari bersinar, radiasi yang dihasilkan dari cahaya matahari ini kemudian ditangkap oleh panel surya fotovoltaik. Panel surya ini merupakan suatu 
Teknik, 37 (2), 2016, 61

pengkombinasian dari beberapa sel surya yang ukurannya sangat kecil dan tipis baik secara seri, paralel ataupun campuran (seri dan paralel), sehingga menjadi sebuah panel surya yang cukup besar dan dapat menghasilkan arus dan tegangan yang besar pula.

Prinsip kerja dari panel surya adalah jika cahaya matahari mengenai panel surya, maka elektron-elektron yang ada pada sel surya akan bergerak dari $\mathrm{N}$ ke $\mathrm{P}$, sehingga pada terminal keluaran dari panel surya akan menghasilkan energi listrik. Besarnya energi listrik yang dihasilkan oleh panel surya berbeda-beda tergantung dari jumlah sel surya yang dikombinasikan didalam panel surya tersebut. Keluaran dari panel surya ini adalah berupa listrik arus searah (DC) yang besar tegangan keluarnya tergantung dengan jumlah sel surya yang dipasang didalam panel surya dan banyaknya sinar matahari yang menyinari panel surya tersebut (Bansai, 1990).

Keluaran dari panel surya ini sudah dapat digunakan langsung ke beban yang memerlukan sumber tegangan DC dengan konsumsi arus yang kecil. Agar energi listrik yang dihasilkan juga dapat digunakan pada kondisi - kondisi seperti pada malam hari (kondisi saat panel surya tidak disinari cahaya matahari), maka keluaran dari panel surya ini harus di hubungkan ke sebuah media penyimpanan (storage), dalam hal ini adalah batere. Tetapi ini tidak langsung dihubungkan begitu saja dari panel surya ke batere, tetapi harus dihubungkan ke rangkaian Regulator, dimana didalam rangkaian tersebut terdapat rangkaian pengisi Batere otomatis (Automatic charger).

Fungsi dari regulator ini adalah untuk meregulasi tegangan keluaran dari panel surya dan mengatur arus yang masuk ke batere secara otomatis. Selain itu Regulator berfungsi untuk menghubungkan dan memutuskan arus dari Panel Surya ke Batere secara otomatis dan juga berfungsi untuk memutuskan aliran arus dari batere kebeban bila terjadi hubung singkat ataupun beban yang berlebihan. Tipe regulator yang dirancang disini adalah tipe modifikasi atau gabungan antara seri dan paralel. Panel Surya sebenarnya dapat langsung digunakan tanpa diberi rangkaian regulator ataupun batere, tetapi ini tidak dilakukan karena dapat membebani kinerja dari panel (akibat adanya beban yang berlebihan) sehingga tidak akan terjadi kerusakan yang fatal pada panel surya tersebut. Selain itu regulator ini juga berfungsi untuk mengamankan dari terjadinya kelebihan beban dari panel surya sehingga panel surya tidak cepat rusak (Widodo dkk., 2010).

Hubungan batere dengan beban adalah dihubungkan paralel langsung ke beban. Jika batere tersebut telah terisi dengan penuh. Untuk melindungi batere akibat adanya beban yang berlebihan (over load) ataupun hubungsingkat pada beban, maka sebelum batere dihubungkan langsung harus melewati rangkaian proteksi. Dimana fungsinya sudah cukup jelas, yaitu untuk memproteksi ataupun melindungi batere akibat adanya beban yang berlebihan (over load) ataupun hubung singkat pada beban.

Jika diinginkan hasil keluaran listrik dari PLTS ini berupa listrik arus bolak-balik (AC) maka PLTS yang sudah dapat mengeluarkan listrik arus searah (DC) ini harus dihubungkan ke sebuah rangkaian elektronik / modul 30 elektronik yang bernama Inverter $D C-A C$. Dimana Inverter $D C-A C$ berfungsi untuk mengubah arus listrik searah (DC) menjadi arus listrik bolak-balik (AC). Setelah arus listrik searah diubah menjadi arus listrik bolak-balik, selanjutnya keluaran dari inverter ini yang telah berupa arus bolak-balik ini dapat langsung digunakan untuk mencatu peralatan listrik dan elektronika yang membutuhkan arus bolak-balik. Besarnya tegangan dan daya keluaran yang dapat dihubungkan kebeban nantinya harus sesuai dengan kemampuan inverter yang dipakai dan besarnya sistem penyimpanan yang digunakan (besarnya ampere hour (AH) atau amper jam dari batere).

Pada penelitian ini dilakukan pengujian pengaruh sudut datang matahari terhadap keluaran sel surya. Hal ini bertujuan untuk mengetahui seberapa besar pengruh sudut datang matahari dan juga seberapa besar pengaruh sudut tersebut dapat diabaikan. Cara pengujian dilakukan seperti Gambar 3.
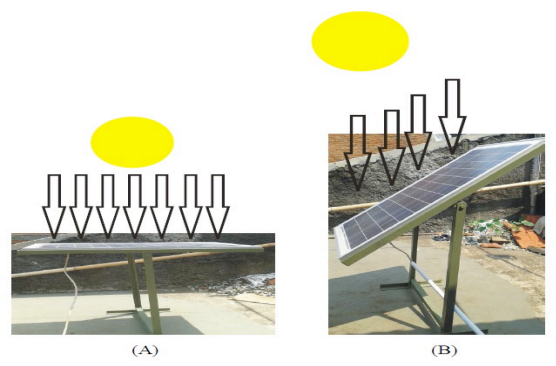

Gambar 3. Pengujian pengaruh arah sudut matahari terhadap keluaran sel surya (a) arah sinar tegak lurus panel (b) arah sinar membentuk sudut tertentu

Pemasangan sebuah panel sel surya dengan posisi tegak lurus terhadap arah sinar matahari seperti Gambar 3a dilakukan untuk mengetahui keluaran maksimum, sedangkan untuk mengetahui pengaruh arah sinar matahari terhadap keluaran panel dilakukan dengan merubah arah panel sel surya tiap $10^{\circ}$ hingga mencapai sudut $45^{\circ}$ terhadap sudut datang matahari seperti Gambar 3b. Dari langkah-langkah tersebut dapat diketahui pengaruh arah sinar matahari terhadap keluaran panel sel surya.

Pengambilan data posisi/sudut matahari sangat diperlukan. Hal ini bertujuan untuk mengetahui seberapa besar pergeseran sudut matahari pada selang waktu tertentu. Pengambilan data ini dilakukan pukul 9.00 hingga pukul 16.00. Hasil pengujian dapat dilihat pada Tabel 1. Dengan menggunakan data pada Tabel 1 diatas 
Teknik, 37 (2), 2016, 62

dapat dibuatkan grafik hubungan antara tegangan rangkaian terbuka terhadap waktu, seperti pada Gambar 4.

Tabel 1. Hasil pengujian tegangan, arus dan daya untuk berbagai posisi sudut sel surya

\begin{tabular}{|c|c|c|c|c|c|c|c|}
\hline \multirow{2}{*}{ NO } & \multirow{2}{*}{ JAM } & \multicolumn{3}{|c|}{ POSISI TEGAK LURUS } & \multicolumn{2}{c|}{ POSISI BENTUK SUDUT } \\
\cline { 3 - 8 } & & $\begin{array}{c}\text { Tegangan } \\
\text { (Voc) }\end{array}$ & $\begin{array}{c}\text { Arus } \\
(\mathrm{A})\end{array}$ & $\begin{array}{c}\text { Daya } \\
\text { Keluar (W) }\end{array}$ & $\begin{array}{c}\text { Tegangan } \\
(\text { Voc })\end{array}$ & $\begin{array}{c}\text { Arus } \\
(\mathrm{A})\end{array}$ & $\begin{array}{c}\text { Daya } \\
\text { Keluar (W) }\end{array}$ \\
\hline 1 & 8.00 & 20,4 & 1,00 & 16,53 & 20,7 & 1,40 & 23,53 \\
\hline 2 & 9.00 & 20,9 & 1,05 & 17,84 & 20,0 & 2,57 & 41,53 \\
\hline 3 & 10.00 & 19,3 & 1,81 & 28,05 & 18,8 & 3,05 & 45,81 \\
\hline 4 & 11.00 & 19,5 & 2,08 & 32,61 & 18,2 & 3,05 & 44,13 \\
\hline 5 & 12.00 & 19,0 & 1,97 & 29,94 & 18,3 & 3,05 & 44,37 \\
\hline 6 & 13.00 & 18,0 & 2,08 & 29,68 & 18,3 & 3,05 & 44,37 \\
\hline 7 & 14.00 & 19,0 & 0,97 & 14,74 & 19,3 & 2,87 & 44,48 \\
\hline 8 & 15.00 & 20,7 & 0,85 & 14,28 & 20,0 & 2,05 & 33,13 \\
\hline 9 & 16.00 & 20,2 & 0,83 & 13,56 & 10,8 & 1,35 & 22,83 \\
\hline \multicolumn{2}{|l|}{ Rata - rata } & 19,67 & 1,40 & 21,91 & 18,27 & 2,49 & 38,24 \\
\hline
\end{tabular}

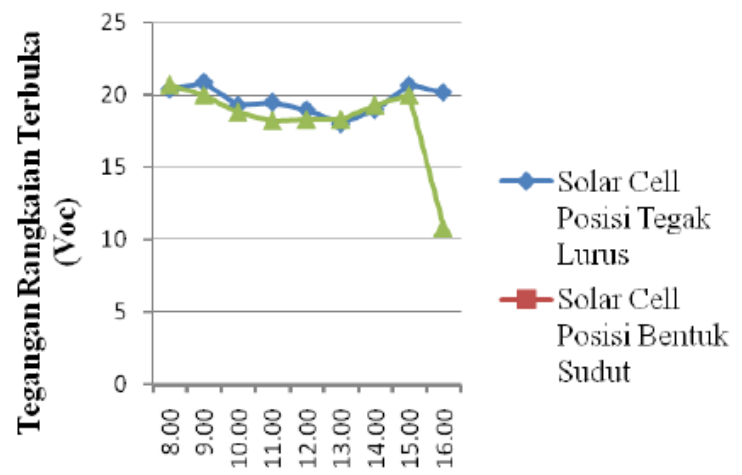

Jam

Gambar 4. Grafik hubungan antara tegangan rangkaian terbuka terhadap waktu pada sel surya

Berdasarkan Gambar 4. menjelaskan bahwa nilai pengukuran rata-rata tegangan rangkaian terbuka pada modul surya posisi bentuk sudut sebesar $18,27 \mathrm{~V}$ dan diperoleh nilai rata-rata tegangan hubung singkat pada saat modul surya posisi tegak (horisontal) sebesar 19,67 V. Perbedaan hasil tegangan rangkaian terbuka (Voc) yang didapat dikarenakan modul surya selalu memposisikan tegak lurus terhadap matahari sehingga hasil yang di dapatkan akan lebih besar dibandingkan dengan modul surya dengan posisi membentuk sudut. Selanjutnya, untuk mengetahui perbandingan arus hubungan singkat terhadap waktu dapat dilihat pada Gambar 5.

Gambar 5 menerangkan bahwa arus yang dihasilkan oleh modul surya yang membentuk sudut lebih besar dibandingkan dengan arus yang dihasilkan oleh modul surya dalam posisi tegak lurus (horizontal) mempunyai sifat statis, hal ini terjadi karena iradiasi yang ditangkap modul surya pada posisi membentuk sudut lebih besar sehingga arus yang ditangkap pada posisi membentuk sudut lebih besar karena semakin besar nilai iradiasi maka semakin besar pula nilai iradiasinya. Dari data hasil pengukuran yang dilakukan maka diperoleh nilai pengukuran rata-rata arus hubung singkat pada modul surya pada posisi membentuk sudut sebesar 2.49 A dan diperoleh nilai rata-rata arus hubung singkat pada saat modul surya posisi tegak lurus (horizontal) sebesar 1.40 A. Untuk mengetahui mengenai lebih lanjut besarnya nilai perbandingan daya keluaran terhadap waktu pada sel surya, dapat dilihat pada Gambar 6.

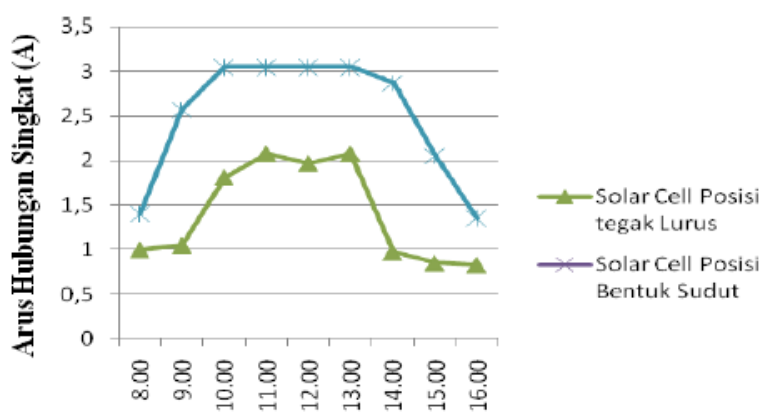

.Jam

Gambar 5. Grafik perbandingan antara arus hubungan singkat terhadap waktu pada sel surya

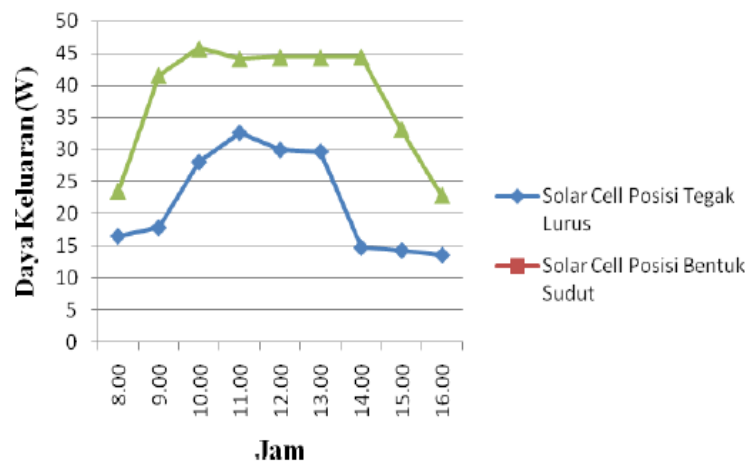

Gambar 6. Grafik perbandingan antara daya keluaran terhadap waktu pada sel surya

Dari tegangan rangkaian terbuka $\left(V_{o c}\right)$ dan Arus hubung singkat $\left(I_{s c}\right)$ yang di dapatkan pada saat pengujian maka dihasilkan daya keluaran dengan mengalikan faktor pengisi (FF) pada modul suryanya sehingga didapatkan grafik perbandingan daya keluaran pada posisi membentuk sudut dengan modul surya pada saat posisi tegak lurus. Daya keluaran rata-rata yang dihasilkan pada saat modul surya posisi membentuk sudut sebesar 38,24 $\mathrm{W}$ dan diperoleh nilai rata-rata daya keluaran pada saat modul surya posisi tegak lurus (horizontal) sebesar 29,6 W. 
Teknik, 37 (2), 2016, 63

\section{Kesimpulan}

Dari hasil analisis desain sistem pembangkit listrik tenaga surya dengan panel surya $50 \mathrm{WP}$ dapat diperoleh kesimpulan sebagai berikut: (a). Karateristik dari Desain yaitu: posisi sudut kemiringan modul surya saat mengikuti arah pergerakan matahari menghasilkan tegangan rata-rata rangkaian terbuka $\left(V_{o c}\right) 18,27 \mathrm{~V}$ dan arus rata-rata hubungan singkat $\left(I_{o c}\right) 2,49 \mathrm{~A}$; dan posisi tegak lurus (horizontal) menghasilkan tegangan rata-rata rangkaian terbuka $\left(V_{o c}\right)$ 19,67 V; sementara itu arus ratarata hubungan singkat $\left(I_{o c}\right) \quad 1,40 \mathrm{~A}$; (b) Posisi sudut kemiringan modul surya saat mengikuti arah pergerakan matahari menghasilkan Daya Keluaran $\left(P_{\text {out }}\right)$ sebesar $38,24 \mathrm{~W}$ dan posisi tegak lurus (horizontal) menghasilkan Daya Keluaran $\left(P_{\text {out }}\right)$ 21,91 W.

\section{Daftar Pustaka}

Akhmad, Kholid, (2011), Pembangkit Listrik Tenaga Surya dan Penerapannya Untuk Daerah Terpencil, Jurnal Dinamika Rekayasa, 1(1): 2833

Anggara, I.W.G.A, Kumara, I.N.S., Giriantari, I.A.D, (2014), Studi Terhadap Unjuk Kerja Pembangkit Listrik Tenaga Surya 1,9 Kw Di Universitas Udayana Bukit Jimbaran, Spektrum, 1(1): 118122.

Hasan, H., (2012), Perancangan Pembangkit Listrik Tenaga Surya Di Pulau Saugi, Jurnal Riset dan Teknologi Kelautan, 10(2): 169-180.
Karmiathi, N.M., (2011), Rancang Bangun Modul Solar Cell Dengan Memanfaatkan Komponen Fotovoltaic Kompatibel, Jurnal Logic, 11.

Rahayuningtyas, A., Kuala, S.I., dan Apriyanto, F., (2014), Studi Perencanaan Sistem Pembangkit Listrik Tenaga Surya (Plts) Skala Rumah Sederhana Di Daerah Pedesaan Sebagai Pembangkit Listrik Alternatif Untuk Mendukung Program Ramah Lingkungan Dan Energi Terbarukan, Prosiding SnaPP 2014 Sains, Teknologi, dan Kesehatan, pp. 223-230

Subandi, Slamet Hani, (2015), Pembangkit Listrik Energi Matahari Sebagai Penggerak Pompa Air Dengan Menggunakan Solar Cell, Jurnal Teknologi Technoscientia, 7(2): 157-163

Ubaidillah, Suyitno, Juwana, Wibawa Endra, (2012), Pengembangan Piranti Hibrid Termoelektrik Sel Surya Sebagai Pembangkit Listrik Rumah Tangga, Jurnal Litbang Provinsi Jawa Tengah, 10(2): 194-211

Bansai, NK, et al., (1990), Renewable Energy Sources And Conversion Technology, Tata McGraw-Hill Publishing Co. Limited, New Delhi

Widodo, Djoko Adi, Suryono, Tatyantoro A, (2010), Pemberdayaan Energi Matahari Sebagai Energi Listrik Lampu Pengatur Lalu Lintas, Jurnal Teknik Elektro, 2(2): 133-138 